\title{
PENGAWASAN ORANGTUA TERHADAP ANAK USIA PRASEKOLAH DALAM MENGGUNAKAN GAWAI
}

\author{
${ }^{1}$ Herni Wulandari, ${ }^{2}$ Deassy Hasanah Siti Asiah, ${ }^{3}$ Meilanny Budiarti Santoso \\ ${ }^{1}$ Program Studi Kesejahteraan Sosial, FISIP, Universitas Padjadjaran \\ ${ }^{2,3}$ Pusat Studi CSR, Kewirausahaan Sosia dan Pemberdayaan Masyarakat Universitas Pajdajdaran
}

\begin{abstract}
ABSTRAK
Penelitian ini ditujukan untuk menggambarkan pengawasan orang tua terhadap anak usia prasekolah saat menggunakan gawai. Pengawasan merupakan kegiatan yang memiliki tujuan agar dapat melindungi dalam bentuk perhatian, sehingga anak dapat berkembang terutama anak usia prasekolah. Dalam menggunakan gawai anak memerlukan pendampingan dari orang tua untuk mengarahkan serta memberikan pemahaman-pemahaman mengenai media yang ditonton untuk menunjang pengetahuan serta persepsi-persepsi positif bagi anak. Adapun aspek-aspek pengawasan orang tua dalam pengawasan anak usia prasekolah yang diteliti dalam penelitian ini adalah mediasi aktif prnggunaan media daring, Mediasi aktif keamanan penggunaan media daring, Mediasi pembatasan, pembatasan teknis, dan monitoring. Aspek-aspek pengawasan orang tua yang diteliti ini agar dapat terhindar dari dampak negatif penggunaan gawai. Pendekatan penelitian yang digunakan dalam penelitian ini adalah pendekatan kualitatif dengan metode deskriptif. Teknik pengumpulan data yang digunakan adalah melalui observasi non-partisipatif, wawancara mendalam, studi kepustakaan dan studi dokumentasi. Hasil penelitian menunjukkan bahwa orang tua sudah melakukan pengawasan dalam penggunaan gawai pada anak, berusaha meluangkan waktunya untuk melakukan pendampingan pada anak, membantu anak ketika mengalami kesulitan dalam pengoperasian gawai, memberikan arahan untuk membuka konten bersifat edukatif, orang tua berusaha menerapkan kedisiplinan waktu penggunaan gawai sebagai bentuk pengawasannya. Terdapat perbedaan antara ayah dan ibu dalam melakukan pengawasan. Belum semua aspek pengawasan dapat dilakukan secara langsung oleh orang tua karena faktor kesibukan pekerjaan, sehingga orang tua belum dapat melakukan perannya pada aspek-aspek tertentu.
\end{abstract}

Kata Kunci: Pengawasan orang tua, Anak Usia Prasekolah, Gawai

\section{ABSTRACT}

This study aims to describe parental supervision of preschool children when using gadgets. Supervision is an activity of observing attentively which aims to protect children so that they can develop, especially preschool children. In using gadgets, children require assistance from parents to guide them and provide insights about the media being watched to support knowledge and positive perceptions for children. The aspects of parental supervision of preschool-aged children examined in this study are active mediation of online media use, active mediation of online media use security, restriction mediation, technical restrictions, and monitoring. These aspects of parental supervision are studied in order to avoid the negative impact of using gadgets. This study uses a qualitative approach with descriptive methods. The data collection methods used are non-participatory observation, in-depth interviews, literature review and document review. The results show that parents provide financial to meet children's physical needs and as a form of supervision parents try to take the time to provide assistance to children when children use gadgets, help children when they experience difficulties in operating gadgets, provide directions for accessing educational content, and try to apply time discipline. Father and mother have differences in carrying out supervision. Not all aspects of supervision can be carried out directly by parents due to the busy work factor so that parents have not been able to play their role in certain aspects.

Keywords: Parental mediation, Preschool Children, Gadget 
Jurnal Pengabdian dan

Penelitian Kepada Masyarakat (JPPM)

\section{PENDAHULUAN}

Menurut data dari Kementrian Komunikasi dan Informatika pada tahun 2018, Indonesia merupakan negara pemakai gawai terbesar ke-4 di dunia setelah Cina, India, dan Amerika Serikat. Gawai dapat digunakan oleh siapa saja baik, salah satunya anak usia prasekolah yang sudah mulai diperkenalkan dengan gawai sebagai media pembalajaran maupun aktifitas sehari-hari.

Pengenalan gawai memiliki ragam manfaat bagi anak usia dini, dikarenakan sejak awal seorang anak sudah familiar dengan teknologi, sehingga dapat meningkatkan kosa kata. Hal ini diperkuat dengan temuan riset Joan Ganz Center di Amerika Serikat (dalam Wulandari, 2016), bahwa anak pada usia lima tahun sebagai pengguna aplikasi edukasi $i$-pad mengalami peningkatan kosakata sekitar $27 \%$, sedangkan pada anak usia tiga tahun mengalami peningkatan kosakata sekitar $17 \%$. Dampak positif lain dari penggunaan gawai bagi anak usia dini adalah dapat merangsang indera penglihatan dan pendengaran anak (Pangastuti, 2017). Akan tetapi, pemakaian gawai pada usia dini secara terus-menerus dapat memberikan dampak negatif terhadap pola perilaku keseharian anak dan memicu terjadinya ketergantungan (Chusna, 2017).

Masalah yang sering terjadi pada anak prasekolah yaitu penggunaan gawai yang berlebihan dan tidak sesuai peruntukan. Paparan layar gawai yang berlebihan dapat menginduksi pelepasan hormon dopamin, sehingga menyebabkan ketergantungan atau kecanduan (Asif 2017). Seperti halnya hasil studi yang dilakukan oleh Trinika (2015) menunjukkan sebanyak 166 anak dari 170 orang yang berusia
3-6 tahun, merupakan pengguna gawai, ratarata mereka bermain gawai hampir setiap hari dengan durasi sekitar 5 menit sampai dengan 5 jam per hari.

Masa anak-anak merupakan pijakan awal tahap perkembangan manusia, atau diistilahkan dengan pondasi awal tumbuh kembang manusia. Dalam pandangan life span, perkembangan anak pada setiap tahapannya akan menjadi dasar bagi tahapan perkembangan selanjutnya (Indrijati dkk, 2016). Masa prasekolah merupakan anak-anak yang berada pada rentang usia 3-6 tahun (Santrock, 2007). Usia prasekolah termasuk dalam generasi Alpha, yaitu anak yang lahir dari tahun 2010 ke atas, terdapat beberapa karakteristik generasi Alpha yang salah satunya adalah sulit untuk dilepaskan dari gawai dan kurang bersosialisasi (McCrindle, 2014).

Menurut Biechler dan Snowman (1993), sebagaimana dikutip oleh Soemiarti Patmonodewo, mengatakan bahwa: Anak prasekolah adalah mereka yang berusia antara 3-6 tahun.

1) Perkembangan Fisik

Perkembangan fisik merupakan dasar bagi kemajuan perkembangan berikutnya. Dengan meningkatnya pertumbuhan tubuh, baik menyakut ukuran berat dan tinggi, maupun kekuatanya memungkinkan anak untuk dapat lebih mengembangkan keterampilan fisiknya, dan eksplorasi terhadap lingkungannya dengan tanpa bantuan orang tuanya. Perkembangan fisik ditandai dengan berkembangnya kemampuan dan keterampilan motorik. Kemampuan motorik tersebut dapat di deskripsikan sebagai berikut:

Tabel 2.1

Perkembangan Fisik

\begin{tabular}{|c|l|l|}
\hline USIA & \multicolumn{1}{|c|}{ Kemampuan Motorik Kasar } & \multicolumn{1}{|c|}{ Kemampuan Motorik Lembut dan Halus } \\
\hline 4 tahun & 1.Naik dan turun tangga & 1. Menggunakan krayon \\
& 2.Meloncat dengan dua kaki & 2. Menggunakan benda atau alat \\
& 3.Melempar bola & 3. Meniru bentuk (Meniru gerakan orang lain) \\
\hline 4-6 tahun & 1.Meloncat & 1. Menggunakan pensil \\
& 2.Mengendarai sepeda anak & 2. Menggambar \\
& 3.Menangkap bola & 3. Memotong dan menggunting \\
& 4.Bermain olah raga & 4. Menulis huruf cetak \\
\hline
\end{tabular}

Sumber: Biechler dan Snowman (1993) 
Jurnal Pengabdian dan

Penelitian Kepada Masyarakat (JPPM)

2) Aspek Perkembangan Kognitif

Tahapan perkembangan kognitif sesuai dengan teori Piaget adalah Tahap sensoriomotor, usia 0-2 tahun pada masa ini kemampuan anak terbatas pada gerak gerak refleks, bahasa awal, waktu sekarang dan ruang yang dekat. Tahap pra operasional usia 2-7 tahun masa ini kemampuan menerima rangsangan, anak mulai berkembang kemampuan bahasanya walaupun pemikirannya masih statis dan belum berpikir abstrak, persepsi waktu dan tempat masih terbatas. karakteristik periode preoperasional ini adalah sebagai berikut:

a. Mampu berfikir dengan menggunakan simbol (symbolic function).

b. Berpikirnya masih dibatasi oleh persepsinya. Mereka mayakini apa yang dilihatnya, dan hanya terfokus kepada satu atribut/dimensi terhadap satu objek dalam waktu yang sama. Cara berpikir mereka bersifat memusat (centering).

c. Berpikirnya masih kaku tidak fleksibel. Cara berpikirnya terfokus kepada keadaan awal atau akhir dari suatu tranformasi, bukan kepada transformasi itu sendiri yang mengantarai keadaan tersebut. Contohnya: Anak sudah mungkin memahami bahwa dia lebih tua dari adiknya tetapi mungkin tidak memahaminya, bahwa adiknya lebih muda darinya.

d. Anak sudah mulai mengerti dasardasar mengelompokan sesuatu atau dasar satu dimensi, seperti atas kesamaan warna, bentuk, dan ukuran.

3) Aspek Perkembangan Bahasa

Hart \& Risley (Morrow, 1993) mengatakan umur 2 tahun, anak-anak memproduksi rata-rata dari 338 ucapan yang dapat mengerti dalam setiap jam, cakupan lebih luas antara. 2 tahun lebih tua anak- anak dapat menggunakan 134 kata pada jam berbeda. Membaca dan menulis merupakan bagian dari belajar bahasa. Untuk bisa membaca dan menulis anak perlu mengetahui bebrapa kata dan beranjak memahami kalimat. Agar anak bisa menambah kosakata dilakukannya lah dengan mengajari anak membaca.
4) Aspek Perkembangan Sosial

Pada usia prasekolah. Perkembangan sosial anak sudah tampak jelas, karena mereka sudah mulai aktif berhubungan dengan teman sebayanya. Tanda-tanda perkembangan sosial pada tahap ini, yaitu:

a. Anak mulai mengetahui aturan-aturan, baik di lingkungan keluarga maupun dalam lingkungan bermain.

b. Sedikit demi sedikit anak sudah mulai tunduk pada peraturan.

c. Anak mulai menyadari hak dan kepentingan orang lain.

d. Anak mulai dapat bermain bersama anak-anak lain, atau teman sebaya (peer group)

Terdapat sebuah riset dari The Asian Parent Insights yang diadakan pada November 2014, pada riset tersebut sebanyak 98 persen dari 2.714 orang tua di Asia Tenggara yang memiliki anak berusia $3-8$ tahun, hasilnya para orang tua mengizinkan anaknya untuk mengakses teknologi berupa komputer, ponsel pintar, atau tablet. Para orang tua ini berasal dari Singapura, Malaysia, Thailand, Indonesia, dan Filipina. Dari hasil survei tersebut, sebagian besar orang tua memperbolehkan anaknya bermain gawai untuk tujuan edukasi. Namun kenyataannya berdasarkan hasil survei, sebagian besar putra-putri mereka menggunakan gawai/tablet tersebut untuk tujuan hiburan seperti permainan (Unantenne, 2014).

Selain itu terdapat survei yang dilakukan oleh Indonesia Hottest Insight pada tahun 2013, menunjukkan bahwa 40\% anak Indonesia sudah "melek" teknologi atau active internet user (Pangastuti, 2017). Penelitian yang dilakukan oleh Trinika tahun 2015 juga menunjukkan bahwa sebesar $42,1 \%$ anak usia prasekolah dengan paparan penggunaan gawai yang tinggi (Nurmasari, 2016). Kementerian Kominfo RI dan UNICEF juga melakukan survei pada tahun 2014, yang menunjukkan bahwa anak menggunakan gawai sebagian besar untuk mencari informasi, relasi sosial dan hiburan (Riset Kominfo dan UNICEF Mengenai Perilaku Anak dan Remaja dalam Menggunakan Internet, 2014).

Merujuk pada survei tersebut, secara umum para orang tua tidak menerima umpan balik yang baik, gawai yang seyogianya 
sebagai sarana belajar untuk menambah ilmu pengetahuan anak agar lebih kreatif justru menimbulkan kekhawatiran bagi para orang tua. Goleman (2000: 28) menegaskan, masa anak-anak merupakan saat yang paling tepat dalam memberikan pelajaran-pelajaran. Crowl, Kaminsky \& Podell (1997: 215) menegaskan, masa anak-anak merupakan tahap yang krusial bagi pengemb angan konsep diri anak. Artinya, pada masa inilah saat yang paling tepat dalam mengajarkan berbagai hal karena ditinjau dari sudut pandang perkembangan, anak sedang berada dalam fase pembentukan awal, jiwanya masih "lentur". Orang tua beranggapan gawai mampu menjadi teman bermain, sehingga orang tua dengan mudahnya memberikan gawai kepada anak usia dini tanpa pengawasan (Chusna, 2017).

Bagi para orang tua, membesarkan dan mengasuh anak memang tidaklah mudah, apalagi mereka lahir di era digital, sehingga memberikan tantangan lebih bagi orang tua. Orang tua kini berada dalam posisi dilematis, pada satu sisi orang tua sebaiknya mendorong dan mendukung anak dalam menggunakan media digital untuk tujuan edukasi dan sosial, di sisi lain orang tua harus dapat mengendalikan dan meminimalkan dampak negatif dari penggunaan media digital pada anak (Livingstone \& Helsper, 2008). Tidak dapat dipungkiri bahwa kini kehidupan anakanak telah terintegrasi oleh teknologi digital, salah satunya gawai. Penting bagi orang tua dalam melakukan pengawasan terhadap penggunaan gawai supaya menciptakan generasi yang tidak terpapar pengaruh negatif dari era digital, namun dapat menggunakan semua media itu dengan baik dan bijak untuk kepentingan yang positif (Rahmat, 2018).

Anak sebagai pihak yang belum memiliki kedewasaan masih cukup rentan terpapar dampak buruk dari media digital, sehingga peran orang tua dalam membimbing anak ketika menggunakan media digital menjadi sesuatu yang krusial. Betapa pentingnya peran orang tua dalam melakukan pengawasan terhadap anaknya tatkala anak tersebut menggunakan gawai, sehingga pengawasan harus selalu dilakukan (Mutmainah, 2011). Beberapa hasil studi menunjukan berkurangnya peran orang tua disebabkan oleh beberapa hal. Pertama, pola kehidupan masyarakat modern telah menuntut para orang tua lebih banyak melakukan aktivitas di luar rumah, sehingga mengurangi kemungkinan orang tua untuk mendampingi anak dalam menggunakan media di rumah (Sarwono, Hendriyani, \& Guntarto, 2011; McCann, 2013). Kedua, perkembangan teknologi media yang semakin pesat menghasilkan adanya kesenjangan antara generasi anak/ remaja hari ini sebagai "digital natives" dan para orang tua sebagai "digital immigrants" (Walker \& Zur, 2011; Mutmainnah, 2011). Faktanya, anak seringkali memiliki kepercayaan diri dan keahlian yang lebih tinggi dalam menggunakan media-media digital (contohnya media daring) daripada orang tua dan orang dewasa lainnya (Livingstone \& Bober, 2006).

Mengontrol setiap konten serta mengawasi anak dalam bermain gawai merupakan suatu hal yang perlu dilakukan. Prasanti (2016) mengungkapkan bahwa orang tua memiliki peran untuk mengontrol dan mendidik setiap kegiatan yang diterima anak, serta ikut berinteraksi kepada anak dengan memberikan penjelasan yang baik dan tepat. Pengalaman masa kanak-kanak dapat mempengaruhi perkembangan otak. Tentunya pendidikan tidak dilakukan begitu saja atau dipaksakan secara cepat kepada anak, tetapi harus disampaikan dengan penuh kasih sayang, menyenangkan, penuh kesabaran, ketekunan serta penuh keuletan. Selain itu disesuaikan dengan tahap-tahap perkembangan anak.

Dalam hal ini, meskipun anak-anak usia dini sudah relatif kompenten dalam penggunaan teknologi, idealnya orang tua tetap berfungsi sebagai fasilitator, guru, dan penjaga dalam pemanfaatan tenologi pada anak-anak mereka (Chiong dan Shuler dalam Nikken dan Schols, 2015). Oleh karena itu, dalam menggunakan gawai tentunya anak memerlukan dukungan dengan dilakukannya pendampingan dari orang tua untuk mengarahkan serta memberikan pemahamanpemahaman mengenai media yang ditonton untuk menunjang pengetahuan serta persepsipersepsi positif bagi anak maupun persepsi yang bersifat negatif, serta dapat meminimalisir dampak negatif terhadap anak dari penggunaan gawai tersebut.

Dalam bekerja dengan anak, menurut O'loughlin (2008:5) jarang sekali pekerja sosial bekerja secara individual, artinya selalu melibatkan keluarga dan orang tua. Anggota 
keluarga memastikan anak tumbuh dan berkembang dengan baik. Pada fenomena ini orang tua memiliki peran melakukan pengawasan pada anak dalam penggunaan gawai. Untuk meningkatkan kesadaran dan aktifitas orang tua, pekerja sosial bisa melakukan proses konseling kepada orang tua dan melakukan kegiatan penyuluhan dalam hal pengawasan ini kepada masyarakat. Tetapi, sebelum proses tersebut dilaksanakan, perlu ada asesmen dan pencarian data untuk memahami lebih jauh spesifikasi fenomena ini dalam keluarga dan masyarakat yang sedang ditangani.

\section{METODE}

Metode dalam menuliskan artikel ini menggunakan metode pendekatan kualitatif. Penggunaan metode kualitatif dipilih peneliti untuk mendapatkan data yang lebih mendalam, lengkap dan bermakna tentang penelitian yang ingin diuji. Peneliti-peneliti kualitatif memiliki tujuan untuk mendapatkan pemahaman yang mendalam akan perilaku manusia dan motifmotif yang ada di belakang perilaku tersebut. Oleh karena itu, pendekatan kualitatif lebih sesuai karena penelitian ini tidak memungkinkan untuk diukur secara tepat dengan hanya menggunakan angka saja. Penelitian ini bermaksud untuk mengetahui, memahami, dan melihat pola mediasi orang tua terhadap penggunaan media anak. Dengan pendekatan kualitatif, peneliti dapat memahami bagaimana orang tua menerapkan mediasi kepada anaknya serta motif yang mendasarinya. Selain itu, peneliti juga hendak memahami konteks natural dari orang tua dan keluarga secara keseluruhan, di mana konteks ini turut mempengaruhi cara orang tua memediasi. Data dalam penelitian ini lebih banyak menggunakan narasi, deskripsi cerita, dan dokumen tertulis.

\section{HASIL DAN PEMBAHASAN}

Beberapa masalah yang muncul dari penggunaan gawai antara lain, cyberbullying, sexting, pencurian identitas, dan juga risiko dari penggunaan gawai yang berlebihan. Penggunaan gawai yang berlebihan dapat memberikan pengaruh negatif pada perilaku, kemampuan, dan perkembangan anak. Berikut merupakan dampak negatif dari gawai yang relevan dengan anak usia prasekolah menurut Febrino (2017), antara lain:

1) Menghambat perkembangan motorik halus. Penggunaan gawai yang cukup dengan sentuhan dapat membuat kemampuan motorik halus anak kurang optimal;

2) Menurunnya kemampuan kognitif anak, seperti berkurangnya fokus, konsentrasi anak menjadi lebih pendek, dan berdampak pada penurunan prestasi belajar anak;

3) Penurunan kemampuan bersosialisasi. Anak terlalu asyik dengan gawainya sehingga anak menjadi kurang peduli dengan sekitarnya;

4) Perilaku emosi yang tidak terkendali. Anak yang telah kecanduan gawai akan marah, menangis, atau berteriak-teriak (tantrum) ketika gawainya diambil. Mereka tidak tahan jika berlama-lama tanpa gawainya.

Perilaku kekerasan atau agresif dapat disebabkan oleh seringnya melihat atau memainkan game yang mengandung konten kekerasan dalam gawai. Berawal dari tantrum, marah-marah yang menunjukkan gejala agresif sampai kepada kekerasan. Hal ini akan menjadi kebiasaan dan jika terus berlangsung dalam jangka panjang dapat menjadi karakter anak.

Penggunaan gawai sebenarnya tidak hanya memberikan dampak negatif namun juga dapat memberikan dampak yang positif selama dalam penggunaannya dapat lebih bijaksana dan tidak berlebihan. Berikut merupakan beberapa dampak positif dari penggunaan gawai bagi anak usia prasekolah (Palupi, 2015), antara lain:

1) Sebagai bahan dasar edukasi bagi anak dapat meningkatkan kreatifitas dan daya pikir anak;

2) Belajar hal-hal baru;

3) Belajar sambil bermain; dan

4) Komunikasi. 
Jurnal Pengabdian dan

Penelitian Kepada Masyarakat (JPPM)

Untuk memaksimalkan dampak positif dan meminimalkan dampak negatif dari penggunaan gawai, terdapat sejumlah strategi yang dapat diterapkan oleh orang tua (Livingstone, 2011), antara lain mediasi aktif tentang penggunaan media daring (diskusi antara orang tua dengan anak terkait dengan konten yang dilihat anak saat menggunakan media digital), mediasi pembatasan (orang tua dalam membatasi penggunaan media pada anak seperti durasi waktu dan konten yang diakses), mediasi aktif mengenai keamanan media daring (mendampingi anak agar anak dapat mengakses media daring lebih aman), pembatasan teknis (memasang perangka lunak untuk memfilter), dan pemantauan (mengecek aplikasi yang dikunjungi anak).

Selain itu gawai juga dapat membantu mengenalkan huruf pada anak dan meningkatkan keterampilan membaca (Jackson, dkk., 2011, dalam (Wu, et al., 2014). Dengan bantuan keyboard pada gawai membantu anak mengenal huruf dan angka. Menurut Pangastuti (2017) dengan tampilan gawai yang semakin canggih juga dapat membantu merangsang indera penglihatan dan pendengaran anak.

Livingstone et al., (2011) membuat strategi pengawasan pengaksesan media daring oleh orang tua pada anak, yaitu:

1) Active mediation of child's media daring use. Strategi ini memposisikan orang tua sebagai rekan anak selama mereka mengakses media daring. Strategi ini mendorong orang tua untuk aktif dalam mengawasi anak, dengan cara berdialog dengan anak tentang konten yang didapat oleh anak dan mengajak anak untuk sharing aktivitas yang telah dilakukan anak selama pengaksesan media daring;

2) Active mediation of child's media daring safety. Strategi ini memposisikan orang tua sebagai pengawas yang mengarahkan anak dalam pengaksesan media daring agar anak tetap aman selama bermedia daring. Pengawasan keamanan ini dilakukan dengan cara membantu anak apabila dirinya mengalami kesulitan selama mengakses media daring atau apabila anak menemukan konten yang tidak layak dikonsumsi dan memberikan rekomendasi kontenkonten dari media daring yang cocok untuk anak;

3) Restrictive mediation. Strategi ini memposisikan orang tua sebagai pembuat aturan pembatasan dalam pengaksesan media daring oleh anak. Orang tua menentukan lamanya waktu pengaksesan, lokasi pengaksesan, aktivitas apa saja yang anak bisa lakukan selama mengakses media daring dan konten apa saja yang boleh diakses oleh anak;

4) Technical mediation of child's media daring use. Strategi ini memposisikan orang tua sebagai orang yang mempergunakan perangkat lunak untuk menyaring dan membatasi konten-konten di media daring yang bisa diakses anak agar anak tidak mengakses konten yang tidak layak dikonsumsi; dan

5) Monitoring. Strategi ini memposisikan orang tua sebagai pelacak aktivitas anak dalam pengaksesan media daring. Orang tua mengecek hal-hal apa saja yang anak akses selama mengakses media daring, mengecek aktifitas anak di situs jaringan sosial, konten emailnya, dan pesan-pesan yang dikirim dan dibuat oleh anak.

Berikut ini adalah proses pengawasan yang dilakukan oleh orang tua terhadap anaknya dalam menggunakan gawai:

\section{1) Mediasi Aktif Penggunaan Media} Internet

Sebagian besar orang tua memiliki kesedian untuk mendampingi anak saat bermain gawai. orang tua menemani anak menggunakan gawai rata-rata 10 menit - 1 jam. Sedangkan anak menggunakan gawai 1-4 jam per hari. Sehingga erat kaitannya jika orang tua menerapkan tipe ini akan memungkinkan anak mengakses konten yang bersifat negatif. Kurangnya waktu dari orang tua dalam hal menemani anak untuk bermain disebabkan oleh jenis pekerjaan yang menyita waktu orang tua 
Jurnal Pengabdian dan

Penelitian Kepada Masyarakat

(JPPM)

e ISSN: 2775 - 1929

p ISSN: 2775 - 1910
Vol. 2 No.1
Hal: 180- sehingga tidak sepenuhnya anak didampingi oleh orang tua.

Bentuk keterlibatan setiap orang tua berbeda-beda dalam mendampingi anak orang tua melakukan pengawasan dengan cara mendengarkan konten yang dintonton oleh anak atau game yang dimainkan oleh anak, mendampingi anak dengan bermain game bersama, mengarahkan dan mengajarkan anak sehingga dapat menstimulus kemampuan literasi anak dan menambah ilmu pengetahuan anak. Hal tersebut sejalan dengan hasil penelitian (Irmayanti, 2018) tentang peran orang tua dalam mendampingi penggunaan gawai pada anak usia prasekolah menunjukan bahwa Ibu yang memiliki latar belakang pendidikan tinggi cenderung memiliki cara cara menarik dalam melakukan pendampingan.

2) Mediasi Aktif Keamanan Penggunaan Media Internet

Pengawasan keamanan ini dilakukan dengan cara membantu anak apabila dirinya mengalami kesulitan selama mengakses internet serta memberikan rekomendasi konten-konten dari internet yang cocok untuk anak.

Dari hasil wawancara bersama informan, anak usia prasekolah sudah mengetahui aplikasi Youtube, game online, whatsapp dan playstore. Selain itu anak usia prasekolah sudah dapat mengoperasikan gawai seperti menggunakan kamera untuk memfoto atau membuat video, berkomunikasi melalui whatsapp dan mendownload permainan. Namun, ketika anak belum bisa mencari apa yang ia inginkan di dalam gawai, anak akan meminta bantuan kepada orang tua.

Orang tua membantu anak terkait dengan pencaharian konten yang akan ditonton oleh anak. Anak juga meminta bantuan kepada orang tua saat anak tidak mengerti mengenai cara memainkan game. Orang tua mengajarkan anak mengenai teknis permainan tersebut. Terkait hal ini orang tua menyadari bahwa anak belum mampu untuk mencari konten sendiri. Selain itu, orang tua tentunya membantu anak jika mengalami kesulitan dalam menggunakan gawai seperti jika muncul iklan pada Youtube atau terjadi kendala pada jaringan.

Mayoritas informan tidak merekomendasikan konten. Hal ini dikarenakan konten yang diakses oleh anak tidak hanya sekedar hiburan tetapi berisi berbagai pembelajaran yang dapat meningkatkan pengetahuan anak. Orang tua terutama ibu yang berpendidikan, mengarahkan anak untuk menonton konten dan bermain game yang bersifat edukatif. Sebagaimana Nurrachmawati (2017) menyebutkan faktor-faktor yang mendukung sebagian besar orang tua memberikan gawai kepada anak yang didasari adanya pengetahuan mengenai dampak positif penggunaan gawai pada anak seperti memberikan pembelajaran dengan perkembangan tekonologi modern bagi anak sehingga dapat menambah ilmu pengetahuan anak tentang dunia luar, dan dapat merangsang perkembangan otak anak.

3) Mediasi Pembatasan

Batasan durasi yang diberikan orang tua dalam menggunakan gawai selama 1-4 jam perhari dan hanya untuk membuka konten atau aplikasi yang diperbolehkan orang tuanya. Sebagian orang tua secara tegas membatasi mengenai kapan anak boleh menggunakan gawai maupun berapa lama anak menggunakan gawai. Menurut asosiasi dokter anak Amerika dan Canada anak usia 3-5 tahun dibatasi 1 jam perhari (Antonius,2016). Tujuannya untuk mencegah anak dari kecanduan gawai. Artinya diluar kegiatan anak sekolah maka internet telah menjadi aktivitas rutin yang anak lakukan. Peran orang tua dalam membuat aturan kepada anak dalam menggunakan gawai dapat dilihat melalui pengetahuan dan wawasan orang tua. Terdapat kecemasan dan kekhawatiran pada para orang tua ketika melihat anakanaknyamenggunakan internet dalam jangka waktu yang lama. Hal yang menarik peneliti, tingginya kekhawatiran orang tua terhadap anaknya dalam menggunakan gawai ternyata tidak membuat orang tua melarang anaknya untuk menggunakan gawai pada anakanaknya. Oleh karena itu para orang tua 
sepakat memberikan aturan pada anakanaknya dalam menggunakan gawai. Orang tua merasa percaya diri karena mengandalkan aturan penggunaan gawai sebagai bentuk mengasuh anak, dan sebagai cara orang tua untuk melindungi anak dan menjaga tetap aman dari dampak negatif penggunaan gawai. Hal tersebut mencirikan pola Authoritative Parenting Style sebagaimana konsep Maccoby dan Martin (1983) yaitu orang tua secara tegas memberikan batasan waktu kapan dan berapa lama anak menggunakan gawai.

$\begin{array}{cccc}\text { Orang } & \text { tua tidak hanya } \\ \text { memberikan waktu } & \text { durasi dalam }\end{array}$ menggunakan gawai. Orang tua memberikan batasan terkait dengan video maupun aplikasi ketika menggunakan gawai. Sebagian besar tidak membatasi namun memberi batasan definitif mengenai situs yang sebaiknya boleh/tidak boleh diakses, atau tidak membatasi karena percaya pada anak. kecenderungan data diatas mencirikan model Permissive Prenting Style (Darling, 1999) yaitu pola pengawasan dengan ciriciri orang tua yang tidak banyak memberikan tuntutan atau batasan pada anak mereka. Meski demikian kategori orang tua yang tidak secara tegas membatasi akses situs internet tetapi orang tua tetap memberikan arahan secara normatif mengenai situs yang pantas dan tidak pantas diakses.

Berdasarkan uraian diatas terkait cara orang tua mengantisipasi dampak negatif penggunaan gawai pada anak prasekolah dengan membuat aturan waktu penggunaan gawai maupun aturan konten dan aplikasi yang boleh dan tidak boleh digunakan oleh anak,terlihat adanya kerjasama ayah dan ibu dalam membatasi serta menerapkan aturan-aturan bagi anak dalam bermain gawai. Sebagaimana Brooks (2011) yang menyebutkan bahwa ketika ibu-ayah merasakan dukungan satu sama lain, kompetensi keduanya sebagai orang tua akan tumbuh, dan interaksi dengan anak menjadi lebih efektif.

\section{4) Pembatasan Teknis}

Sebagian besar orang tua tidak mempergunakan perangkat lunak atau parental control untuk menyaring konten yang ditonton oleh anak. Ibu bekerja lebih nyaman menggunakan strategi tontonan offline dengan mendownload video yang akan ditonton oleh anak dan mengakses menggunakan Youtube Kids. Namun, orang tua yang tidak menggunakan fitur control untuk menyaring konten, menghapus history tontonan agar anak tidak juga mengkosumsi tayangan yang ditonton oleh ibunya dimana hal ini sangat mungkin terjadi mengingat anak mengakses Youtube menggunakan gawai Ibu mereka. Walau dengan begitu juga tetap saja memiliki kemungkinan anak menonton tayangan yang biasa ditonton orang tuanya, karena Youtube akan memunculkan genre tayangan yang biasa ditonton dihalaman home. Hal tersebut sejalan dengan Anwar (2013) mengingat dampak gawai pada anak bisa berakibat negatif, orang tua sebaiknya berlaku bijak dalam memperbolehkan anaknya menggunakan gawai dengan memasang software pengawasan orang tua. Masitoh (2007) mengatakan dilihat dari aspek perkembangannya, anak usia dini memiliki rasa ingin tahu yang kuat dan antusias terhadap banyak hal. Aktivitas eksplorasi dan imajinasi anak menjadi salah satu ciri karakteristik anak. Tidak menutup kemungkinan anak usia dini memiliki rasa ingin tahu terhadap konten-konten yang terdapat di internet.

\section{5) Monitoring}

Pada mediasi ini mayoritas orang tua tidak memeriksa kembali penggunaan gawai setelah anak menggunakannya. sebagian besar anak memakai gawai untuk menonton Youtube, sedikit sekali anak menggunakan gawai untuk bermain game. Sehingga orang tua merasa tidak begitu perlu untuk mengecek riwayat penjelajahan internet anak. Orang tua menganggap mengetahui konten yang sering ditonton oleh anak karena orang tua melakukan pengawasan pada anak.

Terkait game, anak akan meminta bantuan orang tua terkait dengan teknis permainan sehingga orang tua pun mengetahui game yang dimainkan anak. Tidak jarang juga anak meminta bantuan 
dan orang tua melakukan pengawasan terhadap aktifitas anak.

Livingstone et al. (2011), yang menyatakan bahwa parental mediation monitoring dilakukan ketika anak-anak mengalami risiko dan bahaya online, untuk mencegah pengalaman negatif lebih lanjut. bahwa pemantauan mediasi orang tua tidak berpengaruh pada penggunaan internet yang positif

\section{SIMPULAN DAN SARAN}

\section{Simpulan}

Peran orang tua dalam mendampingi penggunaan gawai pada anak memiliki perbedaan antara Bapak dengan Ibu. Peran ayah berupa memantau kegiatan anak dalam bermain gawai dan bermain game bersama. Sedangkan peran ibu turut kepada melakukan mediasi aktif dengan mengajarkan anak menghafal kosa kata bahasa inggris, mengahafal lagu anak-anak, mengenal nama hewan, mengajarkan doa sehari-hari.

Faktor pendukung Bapak dan Ibu dalam melakukan pendampingan penggunaan gawai pada anak usia prasekolah adalah latar belakang pendidikan, sehingga orang tua memiliki pengetahuan mengenai manfaat serta resiko penggunaan gawai pada anak, hal ini menumbuhkan kesadaran yang lebih tinggi akan pentingnya mendampingi dengan melakukan mediasi aktif ketika anak menggunakan gawai dan melakukan pengawasan terhadap anak ketika anak menggunakan gawai. Namun, seluruh orang tua tidak menggunakan perangkat lunak atau parental control untuk membatasi anak menggunakan gawai. Hal tersebut dikarenakan orang tua tidak mengetahui mengenai perangkat lunak yang dapat membatasi anak menggunakan gawai, sehingga memungkinkan anak dapat mengakses konten yang tidak layak.

\section{Saran}

Mengingat dampak gawai pada anak dapat berakibat positif dan negatif, pihak orang tua sebaiknya berlaku bijak dalam memperbolehkan anaknya menggunakan gawai. Salah satu cara bijak tersebut adalah dengan memasang aplikasi pengawas orang tua atau lebih dikenal dengan parental control seperti aplikasi Kakatu Family, Kids Place, dan Youtube Kids. Aplikasi semacam ini sangat efektif untuk orang tua pekerja dan sangat membantu dalam mengontrol aktivitas anak dengan gawainya. Perangkat-perangkat ini memberikan opsi kepada orang tua untuk memblokir konten yang dianggap tidak layak dikonsumsi anak, mampu merekomendasikan konten layak dikonsumsi anak secara otomatis, mampu memantau penggunaan alat elektronik anak, dan membatasi waktu penggunaan alat elektronik anak secara otomatis.

\section{DAFTAR PUSTAKA}

Biechler dan Snowman. (1993). Perkembangan Anak. Pt: Remaja Rosdakarya. Bandung

Fikkers, K. M., Piotrowski, J. T., \& Valkenburg, P. M. (2017). A matter of style? Exploring the effects of parental mediation styles on early adolescents' media violence exposure and aggression. Computers in Human Behavior, 70, 407-415.

Chusna, P. A. (2017). Pengaruh Media Gadget pada Perkembangan Karakter Anak. Media Komunikasi Sosial Keagamaan. Vol. 17, No. 2

Clark, L. S. (2011). Parental mediation theory for the digital age. Communication Theory, 21(4),

Hagen, I. (2007). 'We can't just sit the whole day watching TV: Negotiations concerning media use among youngsters and their parents', Young: Nordic Journal of Youth Research, Vol 15, No 4, pp. 369-393.

Juliadi. (2018). Penyebab Penggunaan Gadget Pada Remaja. Skripsi. Tidak Diterbitkan. FKIP Program Studi Bimbingan Konseling Universitas Riau Kepulauan Batam.

Livingstone, S., \& Helper, E, J. (2008). Parental Mediation and children's Internet use, Journal of Broadcasting \& electronic Meida, 581-599

Maulida, Hidayahti. (2013). Menelisik Pengaruh Penggunaan Aplikasi Gadget Terhadap Perkembangan Psikologis Anak Usia Dini. Jurnal Ilmiah. FKIP, 


\begin{tabular}{|c|c|c|c|c|}
\hline $\begin{array}{c}\text { Jurnal Pengabdian dan } \\
\text { Penelitian Kepada Masyarakat } \\
\text { (JPPM) }\end{array}$ & $\begin{array}{c}\text { e ISSN: 2775 - 1929 } \\
\text { p ISSN: 2775 - 1910 }\end{array}$ & Vol. 2 No.1 & Hal: 180- & April 2021 \\
\hline
\end{tabular}

Teknologi Pendidikan, Universitas Negeri Semarang. Semarang

Novitasari, W., \& Khotimah, N. (2016). Dampak penggunaan gadget terhadap interksi sosial anak usia 5-6 tahun. Jurnal PAUD Teratai, 5(3), 182-186.

Unantenne, N. (2014). Mobile Device Usage Among Young Kids: A Southeast Asia Study. The Asian Parent Insight.

Pristinella, D. (2018). Mempersiapkan Generasi Milenial Ala Psikolog. Jakarta: PT kompas Media Nusantara.

Sari, P dan Mitsalia A. A. (2016). Pengaruh Penggunaan Gadget Terhadap Personal Sosial Anak Usia Pra Sekolah di Tkit Al Mukmin. Jurnal Profesi 13 (2): $73-77$.

Suana \& Firdaus. (2014). Pola Asuh Orang tua Akan Meningkatkan Adaptasi Sosial Anak Prasekolah di RA Muslimat NU 202 Assa'adah Sukowati Bungah Gresik. Jurnal Ilmiah Kesehatan, 7 (2)

Suardi. (2006). Psikologi Perkembanganpada Remaja. Bandung: Raja Grafindo Persada.

Syahra, R. (2006). Informatika Sosial Peluang dan Tantangan. LIPI. Bandung

Valkenburg, P. M., Kremar, M., Peeters, A. L., \& Merseille, N.M. (1999). Developing a scale to assess three different sysles of television mediation: "intstructive mediation", "restrictive mediation", and "social coviewing: Journal of Broadcasting \& Electronic Media, 5266)

Yulianti, Dwi (2010). Bermain Sambil Belajar Sains di Taman Kanak-kanak. Jakarta: PT Indeks

Zakiyah Darojad. (2010). Kesehatan Mental. Jakarta: Haji Masagung 